\section{Świadek w medialnych asamblażach}

Mateusz Borowski

TEKSTY DRUGIE 2018, NR 3, S. 281-294

DOI: $10.18318 /$ td.2018.3.19
Artykuł powstał w ramach grantu Performanse pamięci. Strategie testymonialne, rekonstrukcyjne i kontrfaktyczne w literaturze i sztukach performatywnych XXiXXI wieku, NCN-DFG Beethoven (ID 272538).

\section{Świadectwo i jego media}

Bodaj nikogo nie trzeba przekonywać, że aktu składania świadectwa nie sposób wyobrazić sobie, jeśli nie uwzględni się kwestii medialnego zapośredniczenia. We wstępie do tomu Media Witnessing' Paul Frosh i Amit Pinchevski stawiają wręcz tezę, że świadectwo to prototypowa forma takiego zapośredniczenia minionych wydarzeń i doświadczeń, służące zdaniu relacji tu i teraz. Zarazem, jak dodają, już przekazywanie informacji za pomocą analogowych bądź cyfrowych mediów (w tym również mowy i pisma) zawiera w sobie zalążek aktu świadczenia, szczególnie w sytuacji, kiedy określona technologia rejestracji danych pełni funkcję prymarnego odbiorcy. Natomiast John Durham Peters w opublikowanym w tym samym tomie Witnessing idzie o krok dalej, stwierdzając:

1 Por. P. Frosh, A. Pinchevski Introduction. Why Media Witnessing? Why Now?, w: Media Witnessing. Testimony in the Age of Mass Communication, ed. by P. Frosh, A. Pinchevski, Palgrave Macmillan, London 2009, s. 1 .

\section{Mateusz Borowski}

- dr hab., pracuje na Wydziale Polonistyki Uniwersytetu Jagiellońskiego. Ostatnio opublikował Strategie zapominania (2015) oraz z Małgorzatą Sugierą Sztuczne natury (2017). Redaktor serii „Interpretacje." Kontakt: mateusz. borowski@uj.edu.pl 
„Świadek to paradygmatyczny przypadek medium: to środek, za którego pomocą doświadczenie przekazywane jest tym, którzy nie znają oryginału"2. Tym samym Peters stawia znak równości między świadczeniem jako aktem zarezerwowanym prototypowo wyłącznie dla człowieka i procesami przekazywania danych za pomocą technologii komunikacyjnych. Wprowadza tę analogię zaś przede wszystkim po to, by zwrócić uwagę na nie dość silnie akcentowany dotąd związek między aktem świadczenia i zmiennymi historycznie metodami jego zapośredniczania. Tymczasem, jak przekonuje zarówno Peters, jak i inni medioznawcy ${ }^{3}$, właśnie dzisiaj, w dobie gwałtownego rozwoju nowych technologii komunikacyjnych i form interakcji społecznej, należy ze szczególną uwagą przyglądać się wpływowi, jaki wywierają one na praktyki świadczenia o przełomowych wydarzeniach społecznych, kryzysach politycznych i katastrofach.

Jak refren powraca we wspomnianych już tekstach medioznawczych stwierdzenie, że w wyniku rozwoju technologii cyfrowych, szczególnie przenośnych urządzeń telefonicznych połączonych z siecią cyfrową, akty świadczenia zyskały bezprecedensową skalę i siłę oddziaływania. Obecnie każdy, kto ma dostęp do tych technologii, może prowadzić relację na żywo, a następnie rozpowszechniać zarejestrowane wydarzenie na ogólnodostępnych platformach internetowych. Te nowe możliwości techniczne przyczyniły się nie tylko do powstania takich, na poły amatorskich form działalności publicystycznej, jak dziennikarstwo obywatelskie. Nagrania wideo trafiają także do głównego obiegu informacyjnego, bowiem stacje telewizyjne chętnie korzystają z materiałów, których dostarczają im naoczni świadkowie dramatycznych wydarzeń. Z nowych technologii korzystają również organizacje zajmujące się działalnością humanitarną, takie choćby jak założona w 1992 roku platforma WITNESS. Współpracuje ona z lokalnymi grupami aktywistów z całego świata, dokumentując przypadki naruszania praw człowieka, a jednocześnie wykorzystuje zgromadzone świadectwa w trakcie kampanii mobilizujących zachodnią opinię publiczną do działania. Nie brakuje również takich portali jak CitizenTube (stanowiący część popularnego serwisu YouTube), na których prywatni użytkownicy mogą zamieszczać przygotowane przez siebie materiały, dotyczące bieżących problemów politycznych i społecznych. Zapewne można mnożyć przykłady tego typu technologicznych rozwiązań,

2 J. Durham Peters Witnessing, w: Media Witnessing, s. 26.

3 Por. L. Torchin Creating the Witness. Documenting Genocide on Film, Video, and the Internet, University of Minnesota Press, Minneapolis-London 2012. 
przyczyniających się dziś do rozpowszechniania aktów świadczenia. Skala tych zjawisk sprawia, że powstające dziś prace medioznawcze nie tylko starają się określić nowe wyzwania metodologiczne, jakie stają przed badaczami świadectw, ale także skłaniają do spojrzenia z perspektywy ery cyfrowej na nieco starsze praktyki świadczenia i ich związki z historycznie zmiennymi technologiami medialnymi.

Na znaczącą rolę takiego spojrzenia wstecz zwróciła uwagę Michal Givoni w pracy The Care of the Witness ${ }^{4}$, w której zajmuje się związkami między historycznie i kulturowo zmiennymi praktykami świadczenia a teoretycznymi koncepcjami świadka i świadectwa. Jak przekonująco pokazuje, ustalenia Jeana-Françoisa Lyotarda, Giorgia Agambena, Shoshany Felman i Doriego Lauba, które dostarczyły podstaw obowiązującej w badaniach nad Holokaustem definicji aktu składania świadectwa, w dużej mierze ignorowały jego polityczne i praktyczne konsekwencje. Badacze ci, proponując uniwersalizujące wykładnie tego aktu, uznawali go bowiem za powinność etyczną i fundament podmiotowości - za indywidualny gest oporu wobec oficjalnych narracji historycznych, który ujawniał ograniczenia w komunikacji przeszłych doświadczeń ze względu na pośrednictwo języka i innych form ekspresji. Takie konceptualizacje „przedstawiały katastrofę jako paradygmat ogólnego kryzysu reprezentacji, kryzys reprezentacji traktując zarazem jako najbardziej adekwatną odpowiedź na katastrofę" ${ }^{\prime \prime}$. Utrwalały jednocześnie przekonanie o tym, że świadectwa Holokaustu jako wyjątkowego wydarzenia nie mogą służyć jako prototyp dla innych form świadczenia o ludobójstwach, wojnach czy katastrofach. Givoni zaproponowała krytyczną lekturę kanonicznych prac z dziedziny badań nad świadectwem przede wszystkim po to, by pokazać, na ile te ujęcia, akcentujące etyczny wymiar świadectwa, pomijały jego znaczenie polityczne jako aktu mobilizującego do interwencji w momentach kryzysów. Tymczasem, jak przekonuje, jeśli świadectwo ma dziś zyskać siłę społecznego oddziaływania, należy na nowo zdefiniować jego kształt i funkcję. Dlatego zamiast koncentrować się na kwestii nieprzedstawialności, należy zwrócić uwagę na afektywne oddziaływanie świadectw, stanowiące wynik specyficznych strategii retorycznych i konwencji narracyjnych. Givoni bacznie przygląda się ponadto formom, jakie przybierają świadectwa wykorzystywane przez organizacje humanitarne, które zdają sprawę z aktualnie

4 M. Givoni The Care of the Witness: A Contemporary History of Testimony in Crises, Cambridge University Press, Cambridge 2016.

5 Tamże, s. 91. 
toczących się konfliktów, głównie po to, by zyskać społeczne wsparcie i środki dla interwencji kryzysowych. Oczywiście autorka The Care of the Witness ma pełną świadomość tego, że każdy akt świadczenia jest nieuchronnie uwikłany w relacje władzy. To ona przecież decyduje o tym, kto i na jakich warunkach może zabierać głos w sferze publicznej. Nic dziwnego zatem, że w zakończeniu swojej pracy wielkie nadzieje wiąże z nowymi mediami cyfrowymi, które oferują ogromne możliwości gromadzenia i rozpowszechniania świadectw poza oficjalnymi instytucjami, regulującymi przepływ informacji zgodnie z potrzebami reżimu politycznego.

Na uwagę zasługuje przede wszystkim jeden aspekt tej problematyki, zaledwie wspomniany przez Givoni w zakończeniu książki. Odnotowuje tu ona pojawienie się nowych form świadczenia, które skłaniają do ponownego przemyślenia relacji między świadkiem i świadectwem jako typem medialnego zapośredniczenia. Jak bowiem twierdzi, coraz większą rolę w głównym nurcie życia politycznego odgrywają świadectwa „posthumanistycznych asamblaży", czyli hybrydycznych, ludzko-maszynowych układów, w których ramach technologia zyskuje coraz większą siłę sprawczą. Dość wspomnieć o platformie internetowej Ushahidi, którą wykorzystano w 2010 roku w trakcie trzęsienia ziemi na Haiti. Pozwoliła ona kolektywnie sporządzić kryzysową mapę, dostarczającą aktualnych informacji o stanie zagrożenia w poszczególnych rejonach wyspy. W tym przypadku, jak przekonuje Givoni, jako świadek katastrofy funkcjonowała mapa, powstająca dynamicznie w wyniku integracji danych, które wprawdzie dostarczali ludzie, lecz ich obróbką zajmowało się już wyspecjalizowane oprogramowanie. O podobnym asamblażu mówi Givoni w przypadku projektu Witnessential Cyborg, którego opracowaniem przez kilka lat zajmował się inżynier Steve Mann. Dokumentował on swoje życie za pomocą przenośnej kamery, która rejestrowała wszystko, co znalazło się w jego otoczeniu. Mann nazwał tę formę interakcji z technologią „sousveillance”, czyli nadzór oddolny. Zgodnie z jego intencjami miał on stanowić przeciwwagę dla innych form medialnej inwigilacji, stosowanych przez oficjalne instytucje i organy władzy. Trudno nie zgodzić się z Givoni, kiedy dochodzi do wniosku, że tego typu technologiczne rozwiązania podważają fundamentalne dla koncepcji świadectwa założenie, że powinno ono ocalać typowo ludzką perspektywę spojrzenia na przerażająco nieludzkie kryzysy i katastrofy. Kiedy jednak aktu świadczenia dokonuje ludzko-maszynowa hybryda, musi zmienić się nie tylko sama koncepcja świadka i świadectwa,

6 Tamże, s. 212. 
lecz także przyjęte dotąd sposoby spojrzenia na historyczne związki między mediami i praktykami świadczenia.

\section{Świadek jako asamblaż}

Z punktu widzenia historycznych związków między mediami i praktykami świadczenia szczególnie problematyczne wydaje się założenie, że media to jedynie powolne ludziom instrumenty, służące do wyrażania doświadczeń i relacjonowania minionych wydarzeń. Takie przekonanie leżało u podstaw modernistycznego paradygmatu produkcji wiedzy, który opierał się na zapisie i przechowywaniu śladów przeszłości. W artykule poświęconym literackim świadectwom zagłady Hayden White przekonuje wręcz, że paradygmat ten dyktował nie tylko formy składania świadectw, lecz ponadto również takie sposoby ich czytania, które miały rzekomo gwarantować dostęp do obiektywnego obrazu przeszłości ${ }^{7}$. Interesuje go przede wszystkim problematyczny status świadectw, które - choć powszechnie zaliczane do kategorii tekstów faktograficznych - posługują się literackimi tropami i metaforami, żeby skutecznie oddziaływać afektywnie na odbiorców. W ramach takiego ujęcia świadectwo nie tyle stanowi wyraz doświadczeń tego, kto je składa, ile raczej daje podstawę wytwarzania określonej wizji przeszłości, zależnie od tego, kto i w jakim kontekście je odczytuje. Ta perspektywa, choć niezaprzeczalnie istotna w kontekście interesujących mnie nowych form świadczenia, domaga się jednak uzupełnienia o jeszcze jeden wątek. Nie sposób bowiem mówić o sposobach czytania świadectw, nie uwzględniając tego, w jaki sposób akt ich lektury warunkują medialne technologie, służące do gromadzenia, obróbki i rozpowszechniania świadectw.

Pisał o tym choćby niemiecki medioznawca Friedrich Kittler w artykule otwierającym tom Draculas Vermächtnis ${ }^{8}$, w którym zaproponował oryginalną wykładnię Drakuli Brama Stokera, traktując to kanoniczne dzieło literatury gotyckiej jako „nie tyle powieść o wampirze, ile poglądowy wykład na temat

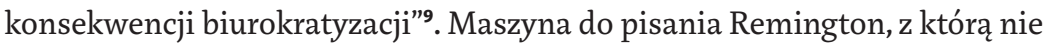
rozstaje się Mina Harker, i fonograf służący doktorowi Sewardowi do rejestracji wywiadów z pacjentami to dwa z powszechnie wykorzystywanych pod

7 H. White Realizm figuralny w literaturze świadectwa, przeł. E. Domańska, w: H. White Proza historyczna, Universitas, Kraków 2009, s. 199-220.

8 F. Kittler Draculas Vermächtnis. Technische Schriften, Reclam, Leipzig 1993.

9 Tamże, s. 43. 
koniec XIX wieku urządzeń, rejestrujących i archiwizujących indywidualne świadectwa. To właśnie te maszyny, które zmieniają świadectwa w dokumenty na drodze swoistej puryfikacji (usuwania wszelkich śladów indywidualnych afektów), stają się tu instrumentami zdobywania zobiektywizowanej wiedzy, do której nie sposób dotrzeć bez ich pośrednictwa. Kittler, analizując Drakule jako tekst wnikliwie diagnozujący fundamentalne problemy formacji modernistycznej, wydobywa bowiem paradoks leżący u samych podstaw funkcjonowania maszyn archiwizujących: dopiero wówczas zmieniają one świadectwa w dokumenty, kiedy oczyszczą je z wszelkich znamion autentyzmu i śladów indywidualnych afektów, łączących je z miejscem i czasem dawnych zdarzeń. Innymi słowy, Kittler identyfikuje tu źródłową dla tego paradygmatu relację między kategorią świadka, która została zarezerwowana wyłącznie dla ludzi, a maszynami jako instrumentami służącymi do konstruowania obrazu przeszłości. Tymczasem już wspomniane i coraz bardziej powszechne formy ludzko-maszynowego świadczenia skłaniają raczej do postawienia pod znakiem zapytania tej binarnej opozycji i zarazem takiego poszerzenia kategorii świadka, by udało się uchwycić rosnącą dziś sprawczość technologii w wytwarzaniu rozmaitych relacji z przeszłością.

Najlepiej dowodzą tego przemiany praktyk świadczenia, które zachodzą dziś w sferze prawnej, a więc w kontekście źródłowym dla nowożytnej koncepcji świadka i świadectwa ${ }^{10}$. O konieczności zmiany podejścia do medialnych zapisów, wykorzystywanych w sądach jako dowody i materiały rzeczowe, przekonuje na łamach niedawnego numeru „The Yale Law Journal” Andrea Roth z Berkeley School of Law. Jak uzasadnia w obszernym artykule Machine Testimony ${ }^{11}$, maszyny pomocne w trakcie postępowania sądowego zyskały już taki stopień autonomii, że „zachowują się niekiedy jak świadkowie: składają zeznania, stanowiące podstawę dochodzenia do prawdy"12. Roth rozpoczyna zaś od stwierdzenia, że rozmaite instrumenty naukowe, aparaty fotograficzne i kamery pełnią istotne funkcje na salach sądowych od co najmniej stu pięćdziesięciu lat. Jednak to ostatnie trzy dekady stały się okresem bezprecedensowego rozwoju technologii, które coraz częściej odbywają się bez udziału człowieka. Chodzi np. o komputerowe systemy monitoringu miejsc publicznych, które nie dość, że działają automatycznie,

10 Por. B.J. Shapiro A Culture of Fact. England, 1550-1720, Cornell University Press, Ithaca-London 2000.

11 A. Roth Machine Testimony, "The Yale Law Journal" 2017 No. 126, s. 1972-2053.

12 Tamże, s. 2001. 
to nierzadko wykazują też inteligentne zachowania, są bowiem tak programowane, żeby w miarę zdobywania informacji z otoczenia uczyły się rozpoznawać potencjalne zagrożenie. Podobną sprawczość ma oprogramowanie do badania próbek DNA, pobranych z miejsca zbrodni. Jednak, jak twierdzi Roth, amerykańskie sądy nadal upierają się przy tym, że informacje dostarczane przez maszyny mogą stanowić jedynie dowody poszlakowe, „ze słyszenia” (hearsay), dowody rzeczowe albo metody badawcze bądź śledcze. Sama Roth tymczasem uznaje, że w obliczu daleko posuniętej autonomizacji technologii należałoby postawić wreszcie znak równości między maszynami i ludźmi-świadkami. Nie chodzi jej przy tym wyłącznie o zmianę nomenklatury, lecz także o prawne konsekwencje takiej zmiany. Zgodnie bowiem z szóstą poprawką do amerykańskiej konstytucji oskarżony ma prawo do bezpośredniej konfrontacji ze świadkiem, który składa obciążające go zeznanie, jeśli chce dokonać weryfikacji jego wiarygodności.

Nietrudno domyślić się, że uznanie maszyn za pełnoprawnych świadków postawiłoby przed aparatem prawnym poważne wyzwanie. Weryfikacja wiarygodności maszyn wymaga przecież nie tylko eksperckiej wiedzy technicznej, ale nierzadko też dostępu do informacji objętych tajemnicą handlową czy chronionych patentami (takich choćby jak kody źródłowe oprogramowania maszyn do testów genetycznych, będących własnością prywatną firm czy korporacji). Dlatego od czasu, kiedy na salach sądowych zaczęły pojawiać się fotografie, włączano je do materiałów dowodowych wyłącznie pod warunkiem, że autor osobiście zagwarantował ich wiarygodność, zaświadczając o tym, że nie zostały spreparowane i że adekwatnie oddają przedstawione wydarzenia ${ }^{13}$. Roth ma jednak świadomość, że zrównanie maszyny ze świadkiem-człowiekiem to daleko idące uproszczenie. Przywołane przez nią przykłady dowodzą raczej, że składane w majestacie prawa świadectwo to efekt interakcji człowieka i technologii czy też rezultat tego, co ona sama nazywa "poznaniem rozproszonym między technologią i ludźmi [distributed cognition between technology and humans]"14. Oczywiście Roth problematyzuje kwestię świadectwa głównie w tym celu, by wskazać na anachroniczność sądowych procedur weryfikowania zeznań maszyn. Choć ten kontekst wydaje się niezwykle istotny w świetle współczesnych

Dziś ten proces stał się znacznie bardziej skomplikowany, gdyż fotografie z kamer przemysłowych czy bankomatów są wyłącznie dziełem maszyny, żaden człowiek nie może zatem dać takich gwarancji.

14 Tamże, s. 2017. 
rozstrzygnięć prawnych, to znacznie bardziej interesuje mnie tutaj związek poruszanej przez Roth problematyki z szerszym kontekstem badań nad przemianami form świadczenia.

Przypomniana przez Roth kategoria poznania rozproszonego sytuuje się w kręgu tych metodologii badawczych, które akcentują sprawczość technologii i ich wpływ na sposób kształtowania obrazu przeszłości. Pokazuje to choćby pouczająca praca Memory ${ }^{15}$. Alison Winter przypomina w niej, że historia XX wieku zna wiele wykorzystywanych w trakcie dochodzeń i na sali sądowej wynalazków, które miały usprawnić proces ustalania faktów. Chodzi jej nie tylko o stosowane do dziś wariografy, ale także o takie technologie z pierwszej połowy XX wieku, które słusznie odeszły w zapomnienie, jak stosowany w latach 20. XX wieku hipnograf. Wysyłał on rytmiczne impulsy świetlne, wprowadzając świadka w stan hipnozy i ułatwiając dotarcie do wypartych lub świadomie ukrywanych wspomnień. Podobny efekt wywoływało serum prawdy, choć za sprawą ingerencji farmakologicznej. Jak twierdzi Winter, te i inne przykłady wspieranych technologicznie metod śledczych pokazują, że maszyny nie tyle pełnią funkcję narzędzi, ile raczej działają jak instancje o znacznie większej sprawczości niż poddawany przesłuchaniu człowiek, który staje się zaledwie biologicznym nośnikiem danych. Dlatego autorka Memory, która przyznaje się otwarcie do inspiracji historycznymi badaniami Foucaulta, nie ma większych wątpliwości, że tego typu ludzko-maszynowi świadkowie to element biopolitycznego zarządzania populacją. Jak podkreśla, za równie istotny, co technologia, element tych heterogenicznych układów należy uznać szersze uwarunkowania instytucjonalne, jakie zrodziła formacja modernistyczna. W latach 20. XX wieku to przede wszystkim psychoanalityczny model wyparcia dostarczył stosownej sankcji naukowej dla nowych metod wydobywania wspomnień, zaś aparat sprawiedliwości musiał włączyć je formalnie w zakres uznanych metod śledczych. Takie ujęcia historyczne, które akt świadczenia traktują jako efekt współpracy ludzi, maszyn, koncepcji i szerokich uwarunkowań instytucjonalnych i społecznych, domagają się nowych perspektyw teoretycznych, akcentujących rosnącą rolę technologii i nie-ludzkich instancji sprawczych w procesie wytwarzania świadectw.

Odpowiednim narzędziem metodologicznym wydaje się w tym kontekście kategoria asamblażu. Wprawdzie wspomniana już Givoni posłużyła się tym pojęciem do opisu współczesnych form świadczenia, w zasadzie nie

15 A. Winter Memory, The University of Chicago Press, Chicago-London 2012. 
podała jego definicji, nie interesowały jej konsekwencje zastosowania go do analizy przemian procesów świadczenia. Tymczasem właśnie asamblaż jako dynamiczna całość, złożona z niejednorodnych elementów, pozwala zakwestionować binarne opozycje leżące u podstaw koncepcji świadectwa. Pojęcie to zaproponowali Gilles Deleuze i Félix Guattari w pracach poświęconych nowej ontologii, przede wszystkim w Tysiąc plateau. Do dyskursu nauk humanistycznych trafiło jednak dopiero za sprawą Manuela DeLandy, który w A New Philosophy of Society ${ }^{16}$ wykorzystał je na gruncie socjologii. Zależało mu bowiem głównie na tym, żeby podważyć podstawowe dla badań socjologicznych przekonanie, że zjawiska społeczne to organiczne i spójne całości, zaś każdy wchodzący w ich skład element ma swoiste dla siebie właściwości (a zatem można go wyodrębnić i zbadać poza kontekstem). Natomiast w późniejszej o dekadę książce Assemblage Theory ${ }^{17}$ DeLanda rozszerzył perspektywę, przekonując, że pojęcie asamblażu może się przydać również na innych polach badawczych jako koncepcja alternatywna wobec wszelkich ujęć esencjonalnych, opartych na binarnych opozycjach. Najistotniejszym bowiem aspektem asamblażu jest to, że właściwości składających się nań elementów nie istnieją autonomicznie, lecz wyłaniają się dopiero w wyniku wzajemnych interakcji. DeLanda wielokrotnie podkreśla ponadto, że wcale nie próbuje obiektywnie opisać rzeczywistości. Chce raczej zaproponować taki punkt widzenia, który akcentuje emergentny charakter zjawisk społecznych i kulturowych, ich dynamiczne stawanie się w sieciach relacji.

O zaletach takiego podejścia świadczyła już wcześniejsza praca War in the Age of Intelligent Machines ${ }^{18}$. DeLanda naszkicował w niej genealogię dzisiejszych maszyn wojennych (rakiet, urządzeń szpiegowskich, symulacji działań wojennych itd.), kierowanych przez złożone systemy sztucznej inteligencji. Zostały one tak zaprogramowane, żeby działać bez ingerencji człowieka, gdyż potrafią same uczyć się na podstawie danych ze środowiska. Oczywiście, pisze DeLanda, człowiek wciąż podejmuje kluczowe decyzje w trakcie działań wojennych, niezaprzeczalnie jednak rozwój technologii prowadzi do stopniowego usamodzielnienia się maszyn cyfrowych. Trudno pominąć ostrzegawczy ton jego pracy. W końcu DeLanda pokazuje, że

M. DeLanda New Philosophy of Society, Bloomsbury, London-New York 2006.

M. DeLanda Assemblage Theory, Edinburgh University Press 2016. 
we współczesnych armiach o rodowodzie z połowy XIX wieku człowiek stał się tylko jednym z elementów maszynowego phylum, czyli asamblażu ludzi i maszyn o rosnącej sprawczości i mocy decyzyjnej. Tak zarysowana genealogia wymagała jednak zmiany przyjętych metod pisania narracji historycznych. Tylko w ten sposób mógł DeLanda uzmysłowić czytelnikom kluczowy w tym kontekście fakt: historię systemów wojennych tworzyli nie tylko ludzie, ale i maszyny jako coraz ważniejsza instancja sprawcza i czynnik wpływający na podejmowanie kluczowych decyzji strategicznych. Dlatego autor War in the Age of Intelligent Machines całkiem serio dodaje, że powinniśmy wysłuchać maszyn jako świadków ich własnej historii, by dostrzec skrzętnie usuwaną w cień sprawczość technologii i odpowiednio zdefiniować na nowo nasze z nimi relacje. Z dzisiejszej perspektywy nie traci zasadności jego podjęta niemal trzy dekady wcześniej decyzja, by stosownie do tych założeń napisać książkę z punktu widzenia robota-historyka, odrzucając antropocentryczną perspektywę i wizję postępu technologicznego na rzecz niehierarchicznych relacji między ludźmi i maszynami.

Jak podkreśla DeLanda, robot-historyk widzi inaczej i coś innego niż człowiek: armię Fryderyka I wyobraża sobie jako mechanizm zegara, a wojska Napoleona jako rodzaj silnika. Wielkich dowódców opisuje nie jako wybitne jednostki o wyjątkowych umiejętnościach strategicznych, lecz jako katalizatory w wielkiej samoorganizującej się machinie wojennej. DeLanda nie pozostawia też wątpliwości co do celu takiej zmiany perspektywy oglądu przeszłości - patrząc na rozwój maszyn z manifestacyjnie nie-ludzkiej perspektywy uda się, być może, lepiej uchwycić zmieniające się relacje między ludźmi i maszynami. O podobną zmianę perspektywy upomina się także wspomniana już Roth, która jednoznacznie stwierdza, że w imię sprawiedliwości musimy dostrzec rosnącą sprawczość maszyn w procesach ustalania prawdy na sali sądowej i odpowiednio zrewidować obowiązujące dziś procedury prawne. Koncepcja asamblażu pozwala jednak na redefinicję świadectwa nie tylko w kontekście prawnym, w którym stanowi ono podstawę dochodzenia do prawdy. Z perspektywy zaproponowanej przez DeLandę można nieco inaczej spojrzeć na funkcję świadectwa w kontekście aktywizmu społecznego i działalności humanitarnej. Tu bowiem relacje świadków mają nie tyle przekazać odbiorcom prawdę o katastrofie, co raczej oddziaływać na nich afektywnie, nakłaniając ich do działania. W ramach koncepcji asamblażu afekt również ulega redefinicji i nie oznacza już typowo ludzkich emocji. Odnosi się bowiem do wszelkiego typu relacji, jakie nawiązują się między elementami asamblażu. Siłę takiego afektywnego oddziaływania 
mają przy tym nie tylko ludzie, ale również inne instancje sprawcze. Dlatego konieczna redefinicja aktów świadczenia w erze inteligentnych maszyn musi również uwzględnić potencjał afektywnego oddziaływania oferowany przez media.

\section{Świadectwo między prawdą i afektem}

Jak podpowiadają Frosh i Pinchevski, to właśnie nowe możliwości rejestracji, archiwizacji i rozpowszechniania świadectw, jakie oferuje technologia wideo od końca lat 6o. XX wieku, doprowadziły do tego, że współcześnie akt świadczenia o rozmaitego typu katastrofach dokonuje się głównie za pośrednictwem mediów. Badacze ci stwierdzają, że współczesne organizacje humanitarne na porządku dziennym wykorzystują w swoich kampaniach modelowe akty świadczenia, nawet jeśli zamiast naocznych świadków pojawiają się aktorzy wypowiadający ich słowa. Te konwencje składania świadectw do kamery to o tyle skuteczne narzędzie retoryczne, że czynią odbiorcę nie tylko depozytariuszem pamięci o katastrofach, ale także potencjalnie mobilizują go do działania na rzecz prewencji lub zażegnania kryzysu. Jak z przekonaniem stwierdzają Frosh i Pinchevski, taka koncepcja nowych mediów jako strażników świadectw zrodziła się w chwili, kiedy w latach 70. zaczęto masowo gromadzić zapisy aktów świadczenia ocalałych z katastrof II wojny światowej. Dość przypomnieć choćby, że od 1979 roku Laub we współpracy z dziennikarką i dokumentalistką Laurel Vlock prowadzili na Uniwersytecie Yale projekt archiwizacji świadectw Holokaustu19. Ówcześnie zapisy te miały upamiętnić katastrofę, w obliczu nieuchronnie zmniejszającej się liczby naocznych świadków Zagłady. Jak przypominają Frosh i Pinchevski, zrodzone w dobie gromadzenia świadectw II wojny światowej przekonanie, że upamiętnienie za pośrednictwem nowych mediów pozwoli zapobiec powtórzeniu się katastrofy, jednocześnie do dziś sankcjonuje praktyki społecznego nadzoru i prewencji za pomocą przenośnych cyfrowych urządzeń komunikacyjnych, kamer przemysłowych i dronów. Innymi słowy, to właśnie technologie medialne umożliwiają pojawienie się świadectwa w sferze publicznej, nie tylko udzielając głosu naocznym świadkom, ale także dostarczając modeli afektywnego oddziaływania na odbiorców, by nakłonić ich do interwencji bądź działań prewencyjnych. 
W pracy Creating the Witness ${ }^{20}$, poświęconej strategiom gromadzenia i rozpowszechniania świadectw ludobójstwa przez organizacje humanitarne, Leshu Torchin stwierdza wprost, że masowe media produkują świadków w efekcie stosowania środków retorycznych, charakterystycznych dla każdej technologii komunikacyjnej. Ma jednak na myśli nie tylko to, że każde medium oferuje uczestnikom wydarzeń inne sposoby ich relacjonowania. Pisze bowiem o "transformacyjnym potencjale świadectwa", które - odpowiednio przygotowane i przedstawione odbiorcom - zmienia ich w równoprawnych świadków wydarzeń, które rozegrały się w innym miejscu i czasie. Dopiero bowiem, kiedy odbiorca stanie się świadkiem, poczuje na swoich barkach brzemię odpowiedzialności za los innych i skłoni go do działania na rzecz przyszłych zmian. Pod tym względem świadczenie o Holokauście nie stanowi wyjątku. Podobne założenia, jak twierdzi Torchin, leżały u podstaw współczesnych praktyk reprezentowania świadectw zagłady już od początku XX wieku, kiedy pojawiła się współczesna koncepcja praw człowieka oraz takie czuwające nad nimi instytucje jak Liga Narodów (1919), a później ONZ (1945). Strategie medialnego wytwarzania świadków na masową skalę stosowano już w okresie tzw. kryzysu Armeńskiego, czyli ludobójstwa Ormian w Imperium Osmańskim w latach 1894-1896, a następnie 1915-1917. Wtedy bowiem, wbrew wysiłkom polityków, próbujących zatuszować akty ludobójstwa, chrześcijańskie organizacje humanitarne organizowały kampanie informujące zachodnią opinię publiczną o skali zbrodni przeciwko ludzkości. Torchin nie ma wątpliwości, że sukces tych akcji w dużej mierze zależał od wykorzystania fotografii i rysunków przedstawiających ofiary Zagłady, które towarzyszyły dziennikarskim relacjom w codziennej prasie amerykańskiej. Już zatem u samych źródeł współczesnych praktyk świadczenia odkrywa Torchin sprawczą rolę mediów jako tej instancji, która wytwarza świadków w dwojakim sensie: nie tylko udziela głosu ofiarom, ale również czyni świadkami adresatów medialnego przekazu. W kolejnych rozdziałach swojej pracy pokazuje ponadto, w jaki sposób typowe dla każdego medium środki i konwencje retoryczne wytwarzają pożądane reakcje odbiorców. Zwraca przy tym uwagę na istotny aspekt tak rozumianego procesu produkcji afektów - zależą one od tego, jak określony kontekst aktualizuje potencjał danego medium, by w konkretny sposób oddziaływać na odbiorców. Innymi słowy, to samo świadectwo może wywoływać odmienne afekty, zależnie od sposobu jego prezentacji. Naocznym dowodem słuszności tej tezy jest przywoływany 
przez Torchin przykład nagłośnionej przez media sprawy pobicia czarnoskórego Rodneya Kinga przez policję w marcu 1991 roku. Nagranie wideo dokumentujące to zajście trafiło zarówno do głównych serwisów informacyjnych, budząc falę społecznych protestów, jak i na salę sądową jako dowód w sprawie przeciwko oskarżonym funkcjonariuszom. Jednak, jak tłumaczy Torchin, te dwa konteksty narzuciły odmienne sposoby oglądania rejestracji, produkując odmienne oddziaływanie afektywne. Stacje telewizyjne prezentowały bowiem tylko ten wycinek nagrania, który pokazywał akt przemocy, tym samym akcentując brutalność policji. Na sali sądowej natomiast to samo nagranie odtwarzano kilkakrotnie klatka po klatce, by umożliwić przysięgłym rzeczową ocenę sytuacji. Nic dziwnego zatem, że tego typu prezentacja narzucała inny rodzaj afektu, neutralizując emocjonalne oddziaływanie na rzecz racjonalnego dystansu. Torchin pisze w tym kontekście o „alchemii między świadectwem i kontekstem jego prezentacji”'21 akcentując asamblażowy charakter aktu świadczenia, którego efekt stanowi emergentny rezultat interakcji między medium i jego odbiorcami.

Spojrzenie na praktyki świadczenia z perspektywy teorii asamblażu okazuje się zatem przydatne nie tylko do badania najnowszych form świadczenia, o jakich pisała Givoni. Z proponowanego przez DeLandę punktu widzenia można jeszcze raz przyjrzeć się również historycznym praktykom i koncepcjom świadka i świadectwa, akcentując ich związek z rozwojem mediów i technologii komunikacyjnych. Jak mi się wydaje, ten punkt widzenia przede wszystkim oferuje możliwość innego ujęcia problematyki kryzysu świadectwa. W miejsce rozważań nad nieprzedstawialnością wprowadza bowiem refleksję nad rozmaitymi typami sprawczości maszyn, podkreślając ich aktywną rolę w procesie społecznego zarządzania informacjami. 


\section{Abstract}

\section{Mateusz Borowski}

JAGIELLONIAN UNIVERSITY (CRACOW)

The Witness in Media Assemblages

New media have changed concepts of witnesses and testimonies. Exploring this development in relation to the notion of the crisis of testimony, Borowski also searches for appropriate forms of describing new practices of giving witness. Methodological approaches to media studies are combined with the theory of assemblage to foreground the effectiveness of communication technologies, which, Borowski argues, have a decisive impact on the shape and course of acts of witnessing, both in the legal context and in the sphere of political activism. This perspective also makes it possible to verify the historical concepts of witnessing and their relationships with analogue media.

\section{Keywords}

witness, testimony, activism, assemblage, digital media 